\title{
International Law before the Courts of the Hong Kong Special Administrative Region of the People's Republic of China- Twenty Years On
}

\author{
LUNG Wan Pun* \\ lung_wanpun@hotmail.com
}

\begin{abstract}
While there have been various studies on international law in domestic courts, the case of the Hong Kong Special Administrative Region of the People's Republic of China [HKSAR], which celebrated its twentieth anniversary in 2017 , presents unique questions. Under the principle of "One Country, Two Systems", while the HKSAR maintains a distinct commonlaw system and a separate judicial regime, foreign affairs remain the responsibilities of the Central People's Government of China. The handling of international law issues in cases before HKSAR courts would require consideration of the constitutional relation between the national (central) authorities of China and the local authorities in the HKSAR, and between the main legal system of China and the local HKSAR common-law system, in the light of the experiences of handling relevant cases in the past twenty years.
\end{abstract}

International law in domestic courts has long been a topic of interest, not only amongst scholars but also in legal practice and international relations. Though not entirely novel, the case of the Hong Kong Special Administrative Region of the People's Republic of China [HKSAR], which celebrated its twentieth anniversary on I July 20I7, presents unique questions on the subject.

\section{HKSAR-A BRIEF OVERVIEW}

Being Chinese territory since ancient times, Hong Kong, having been occupied by Britain after the "Opium War" in I 840, returned to China on I July I997. China established the HKSAR in accordance with the Constitution of the People's Republic of

Formerly Senior Government Counsel (Treaties and Law), Department of Justice, Government of the Hong Kong Special Administrative Region, People's Republic of China. This paper is an abridged and edited version of that presented at the 6th Biennial Conference of the Asian Society of International Law in Seoul, Republic of Korea, on 25 August 2017, and is based on an earlier paper submitted for the Inaugural Conference of the Chinese Judicial Studies Association and the First Chinese Judicial Studies Summit held in Beijing, China on 4 July 2015. Drawing reference from the author's practical experience in the handling of significant international law cases in the HKSAR, the views expressed in the present paper are those of the author only, and do not necessarily reflect those of any institutions with which the author may be associated. 
China and, based on the principle of "One Country, Two Systems", enacted and promulgated a Basic Law of the HKSAR [Basic Law]. Under this Basic Law, the HKSAR would, as a local administrative region coming directly under the Central People's Government, exercise a high degree of autonomy under the authorization of the state. Under the provisions of the Basic Law, in addition to executive and legislative power, the HKSAR enjoys independent judicial power, including that of final adjudication. ${ }^{\mathrm{I}}$ The HKSAR has its Court of Final Appeal vested with the power of final adjudication. ${ }^{2}$ It also maintains a distinct legal system-with the Constitution as the supreme law throughout China, and the Basic Law providing for the system of the HKSAR, the HKSAR largely maintains the pre-existing common-law system in place in Hong Kong. ${ }^{3}$

Furthermore, in order to maintain and fully develop the external relations of Hong Kong as an international centre for commerce and finance, as well as for legal services and dispute resolution, the Basic Law also contains provisions on external affairs, according to which the Central People's Government shall be responsible for the foreign affairs relating to the HKSAR, and the Central People's Government authorizes the HKSAR to conduct relevant external affairs on its own in accordance with the Basic Law. Such external affairs include the application and conclusion of treaties, ${ }^{4}$ as well as participation in international organizations and conferences. ${ }^{5}$

\section{HISTORY OF INTERNATIONAL LAW CASES IN HONG KONG BEFORE I997}

International law issues may often arise in cases before HKSAR courts. Before turning to how HKSAR courts handle such issues, given the continuity of the common-law system previously in place in Hong Kong as provided for in the Basic Law, it would be useful to trace the history of the common law in Hong Kong before its return to China.

\section{A. Application of English Law}

After Hong Kong came under British occupation, the Hong Kong British authorities provided for the application of English law through Section 3 of the Supreme Court Ordinance (Ordinance No. I 5 of I 844): "the law of England shall be in full force in the said Colony of Hongkong, except where the same shall be inapplicable to the local circumstances of the said Colony, or of its inhabitants". After successive

\footnotetext{
I. Art. 2 of the Basic Law.

2. Arts. $8 \mathrm{I}-82$ of the Basic Law. Such judicial power is subject to, inter alia, the power of interpretation of the Basic Law under its art. I 58 (which is vested in the Standing Committee of the National People's Congress [NPCSC]), as well as the provision in art. I9(3) on acts of state, which will be further discussed below.

3. Art. 8 of the Basic Law.

4. See LUNG Wan Pun, "Application and Conclusion of Treaties in the Hong Kong Special Administrative Region of the People's Republic of China: Sixteen Years of Practice” (2013) I2 Chinese Journal of International Law 589 .

5. Constitutional and Mainland Affairs Bureau, HKSAR Government, "HKSAR's External Affairs", online: < http://www.cmab.gov.hk/en/issues/external.htm >.
} 
amendments, the above provision was replaced by the Application of English Law Ordinance (Ordinance No. 2 of 1966; Chapter 88 of the Laws of Hong Kong), which provided in its Section 3 that " $[\mathrm{t}]$ he common law and the rules of equity shall be in force in Hong Kong, so far as they are applicable to the circumstances of Hong Kong or its inhabitants and subject to such modifications as such circumstances may require". The Ordinance remained in force until Hong Kong's return to China. ${ }^{6}$ As issues of application of international law concerned the foreign affairs of the UK, the relevant general principles at English common law were applied to Hong Kong.

In brief, English law adopts a "doctrine of transformation” under which treaties are given the force of law domestically upon enactment of implementing legislation. ${ }^{7}$ While varying views have been expressed on customary international law, ${ }^{8}$ as a general observation, English law largely adopts a "doctrine of incorporation", under which customary international law norms may be adopted as a source of common law, subject to conditions such as compatibility with the domestic constitutional system and statutes. ${ }^{9}$

\section{B. Cases Before Hong Kong British Courts}

These doctrines were applied to Hong Kong by the UK, not only through the abovementioned statutory provisions, but also under case-law. The Judicial Committee of the Privy Council [JCPC] was the final appellate court for the Hong Kong British courts, and the JCPC's decisions on appeals from such courts had precedential effect and were binding on them. ${ }^{\text {IO }}$ The JCPC had indeed decided appeals from Hong Kong involving international law issues, including the often-cited cases of Chung Chi Cheung v. $R^{\mathrm{II}}$ and Philippine Admiral v. Wallem Shipping (Hong Kong) Co. Ltd. ${ }^{\mathrm{I2}}$ on immunities relating to foreign (non-British) states. The JCPC's decisions on appeals from other jurisdictions, and decisions of the House of Lords which had appellate jurisdiction over UK courts under the Appellate Jurisdiction Act I 876, also had very high persuasive authority and were generally followed. ${ }^{13}$ As such, Hong Kong British courts applied English common-law principles in handling cases involving the effect of treaties in local law ${ }^{\mathrm{I} 4}$ and customary international law. ${ }^{\mathrm{I} 5}$

6. See the NPCSC's Decision Concerning the Handling of the Laws Previously in Force in Hong Kong in Accordance with Article I60 of the Basic Law (23 February 1997) [1997 NPCSC Decision], which declared the Ordinance to be in contravention of the Basic Law.

7. JH Rayner (Mincing Lane) Ltd $v$. Department of Trade and Industry, [I990] 2 AC 4I 8 at 500.

8. Such different views have been referred to in e.g. $R v$. Jones (Margaret) and Others, (2006) I32 ILR 668 at 675 .

9. See e.g. Philip SALES and Joanne CLEMENT, "International Law in Domestic Courts: the Developing Framework" (2008) I 24 Law Quarterly Review 388.

Io. Solicitor (24/07) v. Hong Kong Law Society, (2008) I I HKCFAR I I7 at I30-I.

II. Chung Chi Cheung v. R, (I939) 9 ILR 264.

I 2. Philippine Admiral v. Wallem Shipping (Hong Kong) Co. Ltd., (I975) 64 ILR 96.

I3. Supra note Io at I3I-3.

I4. See e.g. Tang Ping-hoi v. Attorney General, (I985) 92 ILR 638.

I 5. See e.g. Lee Bun v. Director of Immigration, (I990) 92 ILR 65 I. 
The above ensured, in cases involving international law issues before Hong Kong British courts, that not only were the laws to be applied, but also that the outcomes of the cases, conformed with the UK's position. This was manifested in the seminal case of Civil Air Transport Incorporated v. Central Air Transport Corporation, ${ }^{16}$ which involved a scheme of the former Nationalist regime in China in "transferring" the aircraft of the state-owned China National Aviation Corporation and Central Air Transport Corporation in Hong Kong to the "Civil Air Transport Incorporated" [CAT] set up by, inter alia, Claire Lee Chennault, former Lieutenant-General in the US Army, so as to prevent the Central People's Government, newly established on I October I949, from recovering such aircraft upon the UK's anticipated recognition of the People's Republic of China. ${ }^{\mathrm{I} 7}$

While the then Supreme Court initially refused in May I950 CAT's application to recognize the "transfer" on the basis of sovereign immunity of the People's Republic of China (now recognized by the UK) before Hong Kong British courts, ${ }^{\mathrm{I} 8}$ as Alexander Grantham, then Hong Kong British Governor, recalled, the US State Department "represented to London that on no account should the planes be given to the Chinese". ${ }^{19}$ The British government subsequently issued the "Supreme Court of Hong Kong (Jurisdiction) Order in Council", ordering that "it shall not be a bar to jurisdiction of the Court that the action or other proceeding impleads a foreign sovereign State". ${ }^{20}$ The Supreme Court still dismissed CAT's application on the basis that the purported "transfer" was "hostile to the present de jure [Chinese] Government and to the interests of the Chinese people". ${ }^{2 \mathrm{I}}$ It was not until 1952 when the JCPC reversed the lower courts' decision on the basis that "retroactivity of [subsequent] recognition operates to validate acts of a de facto Government which has subsequently become the new de jure Government, and not to invalidate acts of the previous de jure Government",22 and that " $[\mathrm{t}]$ he question of motive in effecting the transaction of sale was irrelevant". ${ }^{23}$

While no information has been found on the intentions behind the rulings of the Hong Kong British courts in this case, Grantham noted that while "the law was on the side of the Chinese Government", the British government, "not want[ing] to offend Washington", had to "do a thing of which they have reason to be ashamed" by "wrap[ping] it up in a legal covering". ${ }^{24}$ In any event, this case demonstrated that the Hong Kong British courts were subject to, and had to conform to, the ultimate authority of the UK.

\footnotetext{
16. Civil Air Transport Incorporated v. Central Air Transport Corporation, (I952) I9 ILR 85.

I7. Which took place on 6 January I950.

I8. Civil Air Transport Incorporated v. Claire Lee Chennault and Others, (I950) I7 ILR I73.

I9. Alexander GRANTHAM, Via Ports: From Hong Kong to Hong Kong (Hong Kong: Hong Kong University Press, I965) at I62.

20. S. I(I) of the Order.

2I. Civil Air Transport Incorporated v. Central Air Transport Corporation, (I95 I) 35 HKLR I62 at 207.

22. Supra note I6 at II3.

23. Supra note i6 at i io.

24. Grantham, supra note I9 at I62-3. The Chinese government lodged solemn protests over such rulings of the UK, and confiscated certain British properties in Shanghai. Subsequently, the two countries concluded the Agreement Concerning the Settlement of Mutual Historical Property Claims in 1987, and the UK undertook to pay the Chinese Government US\$3,800,000 to settle, inter alia, claims relating to the two airlines.
} 


\section{HKSAR COURT CASES SINCE I 997}

\section{A. Constitution, Basic Law, and Other National Laws}

As to the present HKSAR, general provisions are found in Article 89(9) of the Chinese Constitution that the State Council, being the Central People's Government, exercises the powers and functions in the conduct of foreign affairs and the conclusion of treaties and agreements with foreign states. Then, Articles I3(I) and I9(3) of the Basic Law stipulate respectively that the Central People's Government shall be responsible for the foreign affairs relating to the HKSAR, and that HKSAR courts have "no jurisdiction over acts of state such as defence and foreign affairs" and are bound by certificates from the HKSAR Chief Executive on questions of fact relating to such acts of state ${ }^{25}$ to be issued upon obtaining certifying documents from the Central People's Government. $^{26}$

That said, neither the Constitution nor the Basic Law explicitly stipulate the domestic legal status of international law in China generally or in the HKSAR locally. While there are several national laws providing for the application of treaties in specific fields, ${ }^{27}$ only a limited number of such national laws are listed in Annex III to the Basic Law and applied to the HKSAR. ${ }^{28}$

\section{B. HKSAR Local Law}

Outside the ambit of the above, the application of international law under HKSAR law has generally been in accordance with common law in place under the provisions of Article 8 of the Basic Law.

As one may observe from the practice of the past twenty years, the position of treaties in HKSAR local law, with which most international law cases before HKSAR courts have been concerned, has been relatively clear. As confirmed on various occasions, including by the Court of Final Appeal in Ubamaka v. Secretary for Security and Director of Immigration, "international treaties are not self-executing" and "unless and until made part of our domestic law by legislation, they do not confer or impose any rights or obligations on individual citizens". ${ }^{29}$ Indeed, this position has been acknowledged in the drafting of the present Article 39 of the Basic Law, which

25. Several other national laws also refer to "acts of state" - see the Administrative Procedure Law (art. I3 (I)), the Basic Law of the Macao SAR (art. I9(3)), the Law on the Garrisoning of the HKSAR (art. 26), and the Law on the Garrisoning of the Macao SAR (art. 26). Also, in art. 2 of the Explanations of Certain Questions Regarding the Implementation of the Administrative Procedure Law (Fa Shi [2000] No. 8) promulgated by the Supreme People's Court, the term "act of state" in the Administrative Procedure Law has been defined to mean "acts of the State Council, the Central Military Commission, the Ministry of Defence and the Ministry of Foreign Affairs etc. concerning defence and foreign affairs performed in the name of the State, and acts of State organs authorized by the Constitution and the law in declaring a state of emergency, martial law and general mobilization etc.".

26. So far such certificates have been issued in cases concerning the diplomatic/consular status of parties concerned. See e.g. Wan Soi Fan Sabina (Zhang Sabine Soi Fan) v. Official Receiver, HCB 472/89.

27. These national laws include the Criminal Law (art. 9 on criminal jurisdiction under international treaties.

28. These national laws include regulations on diplomatic and consular immunities, which implement relevant treaties to which China is party (see XUE Hanqin and JIN Qian, "International Treaties in the Chinese Domestic Legal System" (2009) 8 Chinese Journal of International Law 299 at 306).

29. Ubamaka $v$. Secretary for Security and Director of Immigration, (2OI 2) I 5 HKCFAR 743 at 763. 
provides that the relevant provisions of certain human rights treaties "as applied to Hong Kong" shall "be implemented through the laws of the [HKSAR]", and which reflects the intention of the drafters in recognizing the above established rule in Hong Kong local law. ${ }^{30}$

Conversely, there have been fewer cases before HKSAR courts involving questions of customary international law. While a number of state immunity cases, including FG Hemisphere Associates LLC $v$. Democratic Republic of the Congo and Others $(D R \text { Congo case })^{3 \mathrm{I}}$ which has attracted most attention, have arisen, ${ }^{32}$ together with immigration cases such as $C$ and Others $v$. Director of Immigration and Secretary for Security concerning refugee non-refoulement, ${ }^{33}$ these cases, especially upon reaching the Court of Final Appeal, were generally disposed of by reference to Chinese domestic laws (including HKSAR local laws as appropriate) without engaging in substantive discussion of international law as such. ${ }^{34}$

\section{International Rights and Obligations in Operation Under Different Legal and Court Systems}

Nonetheless, these international law issues before HKSAR courts present a unique question. On the one hand, it is the Central People's Government, as "the sole legitimate government representing in the realm of international relations the whole of China as a subject of international law", ${ }^{35}$ that bears the international rights and obligations arising from the application of international law in the HKSAR, being an inalienable part of China coming directly under the Central People's Government. On the other hand, not only has the HKSAR retained its pre-existing legal system, but, in contrast to the system of appeals to the JCPC for Hong Kong while under British administration, the HKSAR has also been given independent judicial power including that of final adjudication, ${ }^{36}$ though such power is subject to, inter alia, the power of the Standing Committee of the National People's Congress [NPCSC] in the interpretation

30. See e.g. "The Work Report of the Legal Subgroup of the Preparatory Committee for the HKSAR of the National People's Congress" presented at the 8th plenary session of the Preparatory Committee on 3 I January I997 at 46-7.

3I. Democratic Republic of the Congo and Others v. FG Hemisphere Associates LLC (No. I), (20I I) I 47 ILR 376, ILDC I970 (HK 20II) [No. I]; Democratic Republic of the Congo and Others v. FG Hemisphere Associates LLC (No. 2), (20II) I 50 ILR 684, ILDC 2033 (HK 20II) [No. 2].

32. Other state immunity cases include Yeung Kin Ping v. Viet Nam Consulate (in Hong Kong), CACV 74/2010, in which the claim against Viet Nam was dismissed on grounds of consular immunity, rather than state immunity which pertains to consular posts as organs or departments of the sending state (para. Io, commentary on art. 2 of the International Law Commission's Draft Articles on Jurisdictional Immunities of States and their Property I99I); and Lee Mei Chun, Yik Siu Ling and Chan Kwok Chu Joe $v$. Republic of Philippines and Others, HCPI 723-725/20I3, which involved tort claims by HKSAR residents against the Philippine government and officials for personal injuries arising from the Manila hostage-taking incident on 23 August 2010 which were later settled out of court.

33. C and Others v. Director of Immigration and Secretary for Security, (2013) I6 HKCFAR 280. While China is a Contracting State to the Convention relating to the Status of Refugees, 28 July I95 I, I 89 U.N. T.S. I37 (entered into force 22 April I954), the Convention does not apply to the HKSAR.

34. See the judgment of the Court of Final Appeal on the DR Congo case, No. I, supra note 3 I, (2OI I) I 47 ILR 376, at 50I-2. See also ibid., at 302.

35. Lung, supra note 4 at 593; see also art. 4(I) of the International Law Commission's Articles on Responsibility of States for Internationally Wrongful Acts $200 \mathrm{I}$.

36. Arts. 2, 19, and 82 of the Basic Law. 
of the Basic Law, ${ }^{37}$ and that HKSAR courts have no jurisdiction over acts of state such as defence and foreign affairs. ${ }^{3}$ Cases before HKSAR courts are not appealed to the Supreme People's Court. ${ }^{39}$ Also, while the Supreme People's Court, being the highest adjudicative organ of China supervising the administration of justice by all lower People's Courts, ${ }^{40}$ has put in place mechanisms for the handling of international law cases which apply to all lower People's Courts, ${ }^{4 \mathrm{I}}$ such mechanisms do not apply to HKSAR courts.

The question here is how international law cases coming before HKSAR courts can be handled in line with the international rights and obligations of the state of China. While there have only been limited cases before HKSAR courts requiring consideration of this question, the experience of the DR Congo case may offer some insights into how the question may be handled.

\section{EXPERIENCES FROM THE DR CONGO CASE}

\section{A. Facts and Proceedings}

DR Congo was sued in Hong Kong for recovery of compensation from arbitral awards made under contracts on which the Congolese government was said to have defaulted. DR Congo claimed absolute immunity from the jurisdiction of HKSAR courts pursuant to China's position, whereas FG Hemisphere asserted that DR Congo enjoyed only "restrictive immunity" which did not cover the subject matter in the present case. This was the first case in which HKSAR courts were engaged with the question of what the rule of state immunity to be applied in the HKSAR should be, specifically whether the HKSAR, being part of China, had to apply the principle of state immunity as adopted by the state of China at the time (i.e. absolute immunity), or whether it could deviate from such and apply the doctrine of "restrictive immunity" in continuation of the British approach, under either the State Immunity Act $1978^{42}$ or English common law, as applied in Hong Kong before $1997 .{ }^{43}$

37. Art. $67(4)$ of the Constitution; art. I 58 of the Basic Law.

38. Art. I9(3) of the Basic Law.

39. It may be interesting to compare the position of HKSAR courts with that of the HKSAR executive and legislative organs. The Chief Executive of the HKSAR, who heads the HKSAR government (art. 60 of the Basic Law), is subject to express authorization by the Central Authorities in the conduct of external affairs (art. 48(9)); laws enacted by the HKSAR Legislative Council that are not in conformity with Basic Law provisions on matters of responsibility of the Central Authorities (including foreign affairs) may be returned by the NPCSC and immediately invalidated (art. I7(3)). For judicial cases before HKSAR courts, the NPCSC is vested with the power of interpretation of the Basic Law, and HKSAR courts are obliged to refer to the NPCSC questions of interpretation of Basic Law provisions regarding matters for which the Central Authorities are responsible (including foreign affairs) and the relationship between the Central Authorities and the HKSAR. That said, such interpretations by the NPCSC do not affect judgments previously rendered (art. I $58(3))$.

40. See art. I 27 of the Constitution, and the Organizational Law for the People's Courts.

4I. See e.g. the "Notice on the Relevant Issues Concerning the Acceptance by the People's Courts of Civil Cases Involving Privileges and Immunities" (Fa [2007] No. 69, ILDC 2756 (CN 2007)).

42. The UK applied the State Immunity Act 1978 to Hong Kong through the State Immunity (Overseas Territories) Order 1979, which ceased to apply in Hong Kong upon its return to China.

43. For elaboration on the background, see e.g. No. I, supra note 3 I, ILDC I970 (HK 20I I), including paras. $\mathrm{F}_{I}-\mathrm{F}_{7}$ thereof. 
Having gone through successive hearings before the Court of First Instance and the Court of Appeal within the High Court, the case was appealed to the Court of Final Appeal, which delivered a provisional judgment in which it referred to the NPCSC for interpretation of Articles I3 (I) and I9 of the Basic Law regarding the foreign affairs of the state and "acts of state" respectively, ${ }^{44}$ together with expressing a provisional view that the HKSAR could not, "as a matter of legal and constitutional principle", adhere to a doctrine of state immunity that differed from that adopted by the state. ${ }^{45}$ The NPCSC adopted the interpretation of the above Basic Law provisions, ${ }^{46}$ which was followed by the Court of Final Appeal in its final judgment confirming its provisional judgment. ${ }^{47}$

\section{B. Effective Application of International Law}

This landmark case illustrates the basic principles for the application of international law in HKSAR court cases under the Constitution and the Basic Law-that foreign affairs, including those relating to the HKSAR, are the responsibility of the Central People's Government, and that HKSAR laws have to be in conformity with its constitutional status within the state of China and are to be subject to modifications, adaptations, limitations, or exceptions necessary for such conformity, including with the international rights and obligations of the state. ${ }^{48}$

On the other hand, the experience of the DR Congo case presents a practical question of how the above principles may be implemented. Questions relating to treaties arising before HKSAR courts so far may be regarded as being more straightforward, in the light not only of their relative identifiability, but also of express references to treaties within the Basic Law and, as mentioned, the long-standing practice in the common law in place in Hong Kong in requiring implementing legislation which has been acknowledged in the drafting of Basic Law provisions. Conversely, the application of customary international law in Hong Kong may pose more complex questions, including potential implications and impacts of any determination of customary international law issues upon the international legal position of the state.

\section{References from Existing Hong Kong Legislation}

In this regard, while this has not been considered in HKSAR court decisions, in the course of the proceedings of the DR Congo case, ${ }^{49}$ there were discussions on whether issues of state immunity may be disposed of simply by applying Section 6 of the

\footnotetext{
44. No. I, supra note 3I, (20II) I 47 ILR 376, at 50I-2.

45. Ibid., at 435 .

46. See the Official Journal of the NPCSC, 20 I I (No. 6) at 583-93; and, for an English translation, L.N. I36/20I I, Government of the Hong Kong Special Administrative Region Gazette.

47. No. 2, supra note 3I, (20I I) I 50 ILR 684, at 688-9.

48. See the I 997 NPCSC Decision, and art. 4 of the above NPCSC's interpretation.

49. See the judgments of the Court of First Instance (FG Hemisphere Associates LLC v. Democratic Republic of the Congo and Others, [2009] I HKLRD 4IO) and the Court of Appeal (FG Hemisphere Associates LLC $v$. Democratic Republic of the Congo and Others, (2OII) I42 ILR 2 I6).
} 
International Organizations and Diplomatic Privileges Ordinance (Chapter 190 of the Laws of Hong Kong), which presently reads as follows:

Notwithstanding any provision to the contrary contained in any Ordinance, the international custom relating to the immunities and privileges as to person, property or servants of sovereigns, diplomatic agents, or the representatives of foreign powers for the time being recognized by the People's Republic of China shall, in so far as the same is applicable mutatis mutandis, have effect in Hong Kong.

Section 6 of the Ordinance, as originally enacted in I948 as the "Diplomatic Privileges Ordinance" (Ordinance No. 56 of 1948), stipulated that "the law and custom relating to the immunities and privileges ... for the time being in force in England shall ... have effect and be enforced in the Colony". According to the "Objects and Reasons" of the Diplomatic Privileges Bill I948 leading to enactment of the 1948 Ordinance, the purpose of this section was to "assimilate" the law in place in Hong Kong to English law. ${ }^{50}$ Section 6 was amended into the current form in $1999^{5 \mathrm{I}}$ to refer to international custom recognized by the People's Republic of China.

On its face, Section 6 appears to apply to "the privileges and immunities of diplomats and other similar representatives", ${ }^{2}$ and did not appear to be intended to cover the immunity of a foreign state itself; otherwise, for the Hong Kong British courts before 1997, reliance could have been made on this section, rather than the common law or the extension of the British State Immunity Act to Hong Kong, on state immunity issues. Given the various treaties ${ }^{53}$ that govern the privileges and immunities of diplomatic agents, consular officials, and state representatives to international organizations, it may not be surprising that no court case in Hong Kong applying Section 6 has been found. That said, this provision, containing the two limbs of recognition by China and applicability mutatis mutandis, may provide a basis for a mechanism for the application of international law generally, in conformity with the international law rights and obligations of the state of China, while at the same time catering for the particular circumstances of the HKSAR. ${ }^{54}$

On the one hand, as the rights and obligations under international law as applied in the HKSAR are to be assumed by the state, it is important to ensure that the application of international law in the HKSAR conforms to such rights and obligations of China on the international law plane. The first limb, in referring to the application of international custom as recognized by China, seeks to achieve this purpose. On the other hand, certain adaptations may be needed for the application of such custom in the HKSAR given its specific circumstances as a special administrative region of China.

50. See para. 4 of these "Objects and Reasons".

5I. S. 6(b) of schedule 2, Adaptation of Laws (No. 35) Ordinance I999 (Ordinance No. 8I of I999).

52. See the first instance judgment, supra note 49 at 425 . Arguments on the construction of s. 6 were not made on appeal.

53. These are in addition to the national laws applicable in the HKSAR as mentioned above.

54. While this may require further study, the mechanism may be established by several ways, e.g. an interpretation of the relevant provisions of the Basic Law (e.g. art. I3) either on the initiative of the NPCSC or upon request by the HKSAR Court of Final Appeal in the adjudication of cases, or otherwise (art. I 58 ), or by way of national legislation to be enacted by the National People's Congress (or the NPCSC) and made applicable to the HKSAR (art. I8). 
Indeed, this approach has been recognized in China's scrutiny of the then existing laws in Hong Kong in the run-up to Hong Kong's return to China. When examining the Jury Ordinance (Chapter 3 of the Laws of Hong Kong), it was noted that the exemption of "consuls, vice-consuls, and officers of equivalent status, of foreign governments" from jury service under Section $5(\mathrm{I})(\mathrm{c})$ was not specifically stipulated in the relevant national laws on diplomatic and consular privileges and immunities to be applied in the HKSAR (which incorporated relevant treaty provisions). Nonetheless, Section $5(\mathrm{I})(\mathrm{c})$ was considered in line with the general principle of judicial immunity of diplomatic agents and consular officials under these national laws, ${ }^{55}$ and hence was adopted in principle as part of HKSAR laws. ${ }^{56}$ This demonstrates that flexibility is both required and possible in ensuring conformity with China's international rights and obligations and also in accommodating the specific circumstances of Hong Kong.

Also, the approach of Section 6, which is in itself a statutory provision enacted under the common-law system, has the advantage of operability within the common law in the HKSAR. In addition to the second limb of applicability mutatis mutandis as mentioned, which already caters for the specificities of Hong Kong, the first limb of "recognition" by China, which entails ascertaining whether China has as a matter of fact recognized and accepted such custom and what such custom is, may be similar to that adopted not only in HKSAR statutes, ${ }^{57}$ but more importantly in Article I9(3) of the Basic Law on certification regarding acts of state, a mechanism which is also common in various common-law jurisdictions. ${ }^{58}$ The approach of Section 6 may therefore serve as useful reference for the mechanism for application of customary international law, or indeed other international law issues, in the HKSAR legal system.

\section{CONCLUDING REMARKS}

The features of the HKSAR, operating under the principle of "One Country, Two Systems", present a special case in the application of international law. While the experiences of the past twenty years have provided some insights into how international law issues have been, and may be, dealt with under such unique constitutional arrangements, new international law issues may emerge from time to time. Continued efforts between the Central Authorities and the HKSAR would be needed for the further systemization of the handling of issues involving the international rights and obligations of the state, including exploration of possible mechanisms with due regard to the system and practices under the main legal system of China for implementing such international rights and obligations, in conformity with the Constitution and the HKSAR Basic Law and with the principle of "One Country, Two Systems".

\footnotetext{
55. Otherwise, under s. 4(I), persons between twenty-one and sixty-five years of age resident in Hong Kong would generally be liable to serve as jurors. Art. 86 of the Basic Law provides that "[t]he principle of trial by jury previously practised in Hong Kong shall be maintained".

56. See the "Report on the Work of the Legal Subgroup", 3 I January I997, in Compilation of Documents of the Eighth Plenary Session of the Hong Kong Special Administrative Region Preparatory Committee of the National People's Congress (1997) at 53-4.

57. See e.g. s. 7 of the Consular Relations Ordinance (ch. 557 of the Laws of Hong Kong).

58. See e.g. F.A. MANN, Foreign Affairs in English Courts (Oxford: Clarendon Press, 1986) at ch. 3.
} 